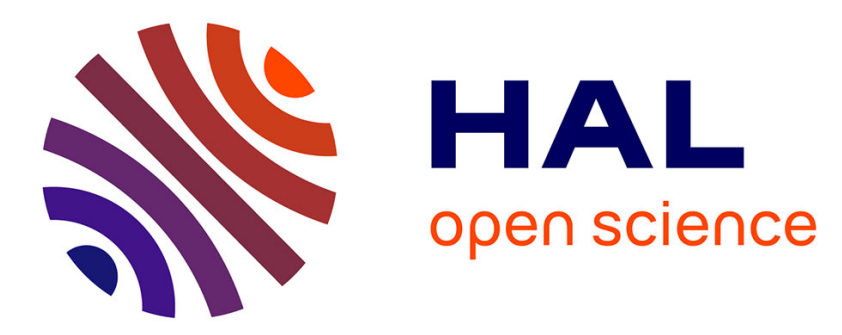

\title{
'(Dis)ordered intensification?' Techno-political models, resource access and pastoralist/agribusiness relations in the Middle Valley of the Senegal River
}

Sergio Dario Magnani, Véronique Ancey, Bernard Hubert

\section{To cite this version:}

Sergio Dario Magnani, Véronique Ancey, Bernard Hubert. '(Dis)ordered intensification?' Technopolitical models, resource access and pastoralist/agribusiness relations in the Middle Valley of the Senegal River. Nomadic Peoples, 2019, 23 (1), pp.5-27. 10.3197/np.2019.230102 • hal-03188276

\section{HAL Id: hal-03188276 \\ https://hal.science/hal-03188276}

Submitted on 6 Apr 2021

HAL is a multi-disciplinary open access archive for the deposit and dissemination of scientific research documents, whether they are published or not. The documents may come from teaching and research institutions in France or abroad, or from public or private research centers.
L'archive ouverte pluridisciplinaire HAL, est destinée au dépôt et à la diffusion de documents scientifiques de niveau recherche, publiés ou non, émanant des établissements d'enseignement et de recherche français ou étrangers, des laboratoires publics ou privés. 
“(Dis)Ordered intensification?” Techno-political models, resource access and pastoralist / agrobusiness relations in the Middle Valley of the Senegal River

Sergio Dario Magnani, Véronique Ancey and Bernard Hubert

https://www.ingentaconnect.com/content/whp/nomp/2019/00000023/00000001/art00002

\section{Abstract}

Since the 1990s, the scientific literature has shown how the technical model of intensification of livestock production is ill-adapted to the characteristics of semi-arid climates and the pastoral systems operating in them. While this led to changes in the rhetoric of pastoral development, there have been no significant shifts in its conceptual foundations and working methods. The article analyses the forms of this persistence, its effects and its causes in the Valley of the Senegal River through a study of the introduction of a social business dairy project into the pastoral area surrounding the city of Richard Toll. The industrial dairy producers and the pastoralists mutually use each other for their own ends, thereby reinforcing the discrepancy between their objectives and the logic of their systems. The model of intensification is persistent because it plays a political role in constructing alliances between actors from agrobusiness, and because choices about land use and resource access are depoliticised and repeatedly made in their favour. The article underlines the urgency of repoliticising and rethinking the logic behind pastoral development and the challenges it faces, and of deconstructing the rhetoric of reconciling profit with social development which serves mainly to reinforce the role that private businesses play in shaping public action.

\section{Keywords: Intensification, Techno-political models of development, Pastoralism, Agrobusiness,} Middle Valley of the Senegal River

\section{Introduction}

From the colonial era to the end of the 1990s, the technoscientific model of intensification of livestock production served as an explicit reference for interventions in pastoral development in semi-arid climates in Africa (Landais, 1990; Scoones, 1994). Its rational approach posits the need to artificialise livestock conditions by limiting their interactions with the environment, in order to secure and increase pastoral production. The model rests on the assumption that it is possible and desirable to overcome the major climatic variability of semi-arid habitats, which is considered to be a risk factor and a constraint, by stabilising pastoralists and their herds and promoting access to water and the use of feed inputs.

Between the 1990s and 2010, a considerable volume of scientific literature showed that this model was not workable because it fails to take into account the ecology of semi-arid climates (Ellis et Swift, 1988; Behnke et Scoones, 1993; Homewood, 2008) and the characteristics of pastoral systems (Krätli, 2007, 2008; Krätli et Schareika, 2010). These critiques have led to a change in rhetoric evident in certain policy texts in the sector and political agreements at continental (Union Africaine, 2013), regional (Déclaration de N'Djamena, 2013) and national levels (Government of Kenya, 2012). However, a major discrepancy remains between this growing formal recognition of pastoral systems and their characteristics, and the persistence of conceptual and methodological foundations reflecting the old paradigm (Krätli, 2016), and thus between the current state of knowledge and the nature of interventions which continue to restrict pastoral mobility, privatise access to natural resources and fragment rangelands. Modes of action ignore significant advances in understanding, which show how these 
interventions compromise the abilities of pastoralists to maintain a complex relationship with the environment and to exploit climatic variability as a factor of production (Galvin et al. 2008; Catley et al. 2013).

The Middle Valley of the Senegal River offers an example of these dynamics. Fifty years of public action have seen the pastoralists excluded from the Valley, which was steered towards irrigated agriculture. Having been thus "stabilised" in the hinterland, they have lost access to the differentiated habitats that they used during the seasonal transhumance, and have come to rely on only the pastures of the dry zone, which vary greatly from place to place and from year to year. The Valley is currently the focus of growing investment in the agrobusiness sector, with new hydro-agricultural developments even in the hinterland, on rangelands and forested areas that constitute important pastoral resources (Koopman, 2012a; RE:COMMON, 2015; Soullier et al. 2016).

After having questioned the pertinence of these objectives of standardising and stabilising pastoral systems in light of the changes in pastoral practices in the Middle Valley, we will look beyond the current modernist rhetoric to examine why intensification and its underpinning are so persistent in shaping pastoral development and public action in this region of Senegal.

The article draws on data produced during doctoral research into dairy production in Senegal (Magnani, 2016) ${ }^{1}$ with a particular focus on the social business project of an industrial dairy which has collected pastoral milk from around the city of Richard Toll since 2006. The dairy proposes a model integrating the local sugar industry and pastoralists to stabilise pastoral production and even promote social harmony between the two groups, in a context of historical tension over land grabbing by industries. Feed inputs (sugarcane residues and industrial cattle feeds) are available on credit to sedentarise dairy cows throughout the year.

We are thus interested in studying the introduction of the dairy's social business into this context, the deployment of its collection and development programmes and the reaction it has provoked among pastoralists. Finally, the industry's contradictory views of pastoral systems and the role of intensification are discussed, in relation with the dynamics of the expansion of agrobusiness in the Senegal River Valley.

\footnotetext{
${ }^{1}$ Fieldwork was carried out for a total of twelve months between 2011 and 2013, combining the study of local written sources with open interviews (139) and participant observation. In the Middle Valley, we studied the interactions between the dairy business and pastoralists, in light of the historical context of development interventions. On one hand, we focused on the interests, logic and visions of the industrial dairy producers and their allies. Interviews were held with dairy staff members (the CEO, directors of collection, collectors, technicians), and stakeholder representatives (danone.communities, Crédit Agricole, NGO Gret, CSS). On the other hand, we monitored five extended families of Fulani pastoralists in the jeeri of Richard Toll and their attitudes to milk collection and technical packages. Families varied in terms of: level of participation in collection; access to dairy markets; livestock systems; family composition and organisation. Extended stays were repeated over three years participating in routine activities and engaging in discussions with family members (the head of family, his brothers and other relatives, his wife/wives, their children and their wives). Every year, we met some of these pastoralists on their transhumance routes. In addition, ad hoc surveys were conducted with five other families to discuss and test specific findings.
} 


\section{The politics of livestock production in African drylands and the pastoral world}

\section{Intensification: a driver of livestock production policies in African drylands}

Intensification, i.e. the improvement of techno-economic productivity, is a dominant technical model in agronomic and zootechnical sciences which has provided the conceptual frame of reference in the development of agriculture and livestock farming in the majority of industrialised countries. It follows a linear logic with "intensive" inputs (fertilisers, phytosanitary products, cattle feed, water, etc.) used to liberate plant and animal systems from environmental constraints and so maximise production (Griffon et al. 2015: 43). As applied to livestock farming, this model, further drawing on negative portrayals of pastoralism, has been the principal force shaping interventions in pastoral development in African drylands (Bernus, 1990; Pouillon, 1990; Hodgson, 1996; Ancey et Monas, 2005).

While colonial activity in the livestock sector in the Sahel was dominated by the battle against epizootics, with independence, public intervention increasingly took the form of pastoral hydraulics systems (Boutrais, 1989). Pastoral hydraulics programmes, which received funding from the 1950s onwards, aimed to ensure that pastures, hitherto used on a seasonal basis when temporary water sources (pools and sumps) appeared, could be exploited all year round. This reflected public authorities' stated aims of increasing herd sizes, sedentarising pastoralists and modernising livestock farming (Baroin, 2003). Numerous "modern" structures, cement wells and mechanised boreholes, were built to complement, or replace, artisanal wells and sumps in pastoral areas. While pastoral hydraulics systems had a number of positive effects, they nonetheless had a major disadvantage in destructuring local ways of regulating access to rangelands, which in the Sahel are based on priority usage rights granted on the grounds of cultural or territorial belonging, on socio-political relations, and on participation in the construction and upkeep of water points. Pastoral hydraulics promoted "public" access to water and pastures (Thébaud et Batterbury, 2001: 76). The public infrastructure and the high flow rate of mechanised boreholes saw cattle become more concentrated, mobility practices change and seasonally-used pastures being permanently occupied (Thébaud, 1990). This failure to consider the social and political dimensions of water management in pastoral areas provoked forms of resistance and conflict (Bernus, 1992).

At the same time, a misunderstanding of pastoral mobility led decision-makers to promote land use that was illadapted to the climate and characteristics of pastoral societies. Ranching and other forms of rational management of pastures, implemented between the 1960s and the 1990s, aimed to integrate livestock farming commercially and limit the supposed degradation of rangelands. Based on incompatible concepts brought in from other contexts, these forms of managing pastures through enclosure had a number of negative effects: land became fragmented (Galvin et al. 2008); pressure on "free" pastures increased (Tache, 2012); pastures were suboptimally exploited; biodiversity was lost; exclusion and conflict increased (Oxby, 1981; Thébaud et al. 1995; Catley et al. 2013).

Organised in the wake of severe droughts, the 1977 United Nations International Conference on Desertification examined the phenomenon of drying in the Sahel, attributing responsibility to local systems of landholding and pastoral activity (Bernus, 1984; Fratkin, 1997). This hypothesis legitimised policies to reduce mobility that drew on thinking lacking any scientific foundation (Swift, 1996; Behnke et Mortimore, 2016; Davis, 2016). Indeed the 
continuity in the way development services thought about problems and their solutions in Sahel environments explains the persistence of ill-suited conceptions of land management. Thus, from the 1980s and 1990s, models of integrated natural resource management called for local plans in order to promote decentralised resource management (De Haan, 1994). However, the plans were implemented using a bureaucratic vision of participation and a simplistic and apolitical conception of the "community". Their implementation at the level of the village was ill-suited to pastoral systems and practices (Marty, 1993) because they underestimated the central role played by mobility in the Sahel and the low level of pastoralist representation in rural councils (Khazanov, 1994; Batterbury, 1998).

Administrations in the second half of the twentieth century primarily sought to promote exclusive land use and the growth of sedentary forms of livestock farming. Pastoralists faced with land fragmentation were less able to rely on their mobility to find unstable resources and were deprived of irreplaceable resources. Propositions to increase the use of feed inputs and replace local races of cattle often lacked any analysis of their economic and ecological sustainability (Boone et al. 2008).

Since the start of this century, a better understanding of the realities of pastoral systems has led to changes. Pastoral hydraulics systems have, in certain contexts, been introduced with the help of close analyses of local land use and sociopolitical dynamics, as well as inclusive concertation processes (Krätli et al. 2013). Furthermore, over the last fifteen years the majority of West African Sahel countries have drawn up legal texts concerning pastoralism showing significant advances (recognition of pastoral mobility and transhumance corridors, etc.). However, the effects of these measures were minimised by a number of major problems: pastoral use of the land which remains secondary to infrastructure investments; a poor understanding of interactions between pastoralism and agriculture; the very limited application of legal texts (Hesse et Thébaud, 2006).

Despite the formal recognition of the value of pastoral practices, intensification remains, especially in recent qualified forms such as sustainable intensification, both the standard technoscientific paradigm in pastoral development in Africa and an underlying factor in the continuity of land and agricultural policies that disadvantage pastoralism.

\section{New ways to look at pastoralism and the management of uncertainty: putting variability at the heart of production}

While the goals of stabilising and standardising pastoral production have persisted (Krätli, 2016), a series of multidisciplinary scientific works over the last twenty-five years have renewed the understanding of the complex interactions between pastoral systems and semi-arid habitats. For Krätli (2017: 142), this change stems from a reexamination of the notion of ecosystem equilibrium in ecology in the 1970s, and the influence of this thinking in the ecology of arid climates and the understanding of pastoral systems in the 1980s. A number of studies have shown that such habitats, characterised by rainfall patterns with systematic spatial, inter- and intra-annual variability, cannot be considered as being stable and in equilibrium (Ellis et Swift, 1988; Behnke et Scoones, 1993; Scoones, 1994). In these environments, the rains constitute the principal factor determining the presence and evolution of plant species which are subject to random and changing dynamics. These studies have contested the 
scientific validity of notions underpinning the models of rational pasture management in these environments, such as carrying capacity (Sayre, 2008; 2017), and overgrazing, thought to lead to desertification. The studies have thus laid the foundation for a better understanding of pastoral systems, recognising mobility as an essential practice that encourages the dispersal of cattle and limits pressure from herds during the annual growing season on which pastures rely (Turner, 2011). The degradation of rangelands is thus attributed to attendant circumstances such as severe constraints on the mobility and growth of herds brought on by the extensive use of cattle feeds (Homewood, 2008: 69).

Scientific and political approaches to risk-aversion and vulnerability reduction have interpreted mobility and other strategic pastoral practices (such as diversification) as a means to minimise the dangers posed by the climate (Ancey et al. 2009: 5). At the same time, close studies of the practices of certain groups of Wodaabe pastoralists in Niger (Schareika, 2003; Krätli, 2007) have shown how climatic variability can be an opportunity to be exploited rather than a risk to be minimised. Variable rainfall and a diversity of soil types, topographies and vegetation allow mobile pastoralists to exploit a range of different pastures at the optimum stage of their growth and over a longer period than in stable and homogenous climatic conditions (Krätli et Schareika, 2010). This capacity to exploit the short-term effects of climatic variability on the nutritional value of plants, at both a small and a large scale, is the key to ensuring high-quality animal nutrition to improve the performance of herds of local races selected for such demanding conditions on the basis of their ability to withstand periods of undernutrition without danger (Krätli, 2015: 19-20). Whether variability represents a risk or an opportunity depends on the characteristics of the livestock systems and their capacity to manage uncertainty from one day to the next (Roe et al. 1998; Krätli, 2015). This calls into question the universality of the notion of intensification evaluated against the criteria of efficiency (per animal, unit of surface area or worker), founded on the idea of overcoming the environment through inputs, capital and investment in infrastructure. For Krätli (2008), other "intensive" factors (knowledge, qualified labour, relationships) underpin pastoral production and constitute forms of social, cultural and political organisation in pastoral societies. The strong identification and cohesion between the social group and its animal component, as seen in the selection of races, plays an essential role in the construction of an active relationship with the environment (Krätli, 2007). Relationships and sociopolitical knowledge underpin not only pastoralists' mobility but also flexible and negotiated access to services and resource creation in the land they use (Schareika, 2003; Bonnet et al. 2013; Casciarri, 2013).

In habitats in which risk-taking is structural and can be advantageously exploited, pastoralists accentuate the flexibility and diversity of their production systems to exploit a wide range of potential situations (Krätli, 2015: 41). This entails maximising the options available, for example by maintaining multiple transhumance routes, dividing the herd and the family at strategic moments, or building complementary relations with agriculturalists (Bonnet et al. 2015). Emery Roe (2013) emphasises the management of the structural variability of the environment through a range of options for possible action, together with flexibility and know-how in real-time implementation, as the key factors in the efficient management of uncertainty in domains of public action subject to high levels of risk (airport traffic, energy flow management, etc.). Drawing on Roe's approach, Krätli (2017a) underlines an inherent paradox in pastoral development in the drylands: in considering variability in the environment and in systems of production as a problem to be minimised, pastoral development interventions in 
fact reduce the internal flexibility of pastoral systems that allows pastoralists to manage and exploit climate variability. Instead of inducing stability, this process exacerbates the turbulence engendered by climate variability and results in more vulnerable pastoral systems.

This paradox is particularly characteristic of the relationship between development and pastoralism in the Middle Valley of the Senegal River.

\section{Pastoralism, development and agrobusiness in the Middle Valley of the Senegal River}

\section{Development interventions and dynamics of change in pastoral systems}

The Valley of the Senegal River has long been settled, giving rise to complex and powerful political structures at a regional level. As a result it is home to a variety of different populations including Toucouleurs, Fulani, Moors, the Bambara and Wolofs (Boutillier et al., 1962: 15-21). Land use management in the Valley was historically structured by two adjacent and heterogenous agro-ecological zones: the waalo, the riverbed and floodplain, and the jeeri, the dewatered dune area which runs parallel to the Valley. Until recently these two areas, each defined in opposition to the other, were used for agriculture and livestock farming in a complementary manner (Schmitz, 1986). The waalo was organised into strips running perpendicular to the river, allowing for different uses of the land throughout the season: fishing during flood periods, followed by flood-recession agriculture and then livestock farming to consume residues left after the harvests of the dry season (Boutillier et Schmitz, 1987: 540). Pastoralists practised seasonal transhumance migrations between the waalo and the jeeri. The jeeri was exploited from the beginning of the rainy season until the ponds dried out during the cold dry season. During the hot dry season, the pastoralists moved to the Valley to feed their herds with agricultural residues, manure the fields and exchange their produce with agriculturalists. This system was practised in a number of different ways, allowing pastoralists to provide high-quality and diversified nutrition to their herds throughout the year (Touré et Arpaillange, 1986). From the 1950s onwards, a vast programme of pastoral hydraulics was implemented in the jeeri, and more generally in the whole pastoral region of the Ferlo, with a view to facilitating the permanent exploitation of pastures and sedentarising the pastoralists. The construction of boreholes led to a major decline in transhumance migrations to the waalo, engendered the relative stabilisation of pastoralists in rainy season camps and meant the rules governing the use of pastures around ponds in the jeeri were abandoned (Barral, 1982).

From the 1970s onwards these changes were amplified in the Lower and Middle Valley by new hydro-agricultural programmes which were developed with a view to diversifying both subsistence and industrial agriculture following the construction of a network of dams. In this context, the Compagnie Sucrière Sénégalaise (CSS), the largest agro-industry in the country, was created in Richard Toll in 1970. This redevelopment of the Valley as an exclusively agricultural area was one of the factors ${ }^{2}$ behind the end of transhumance migrations to the waalo, entailing the loss of seasonal access to heterogeneous resources that complemented the pastures of the jeeri. Extended families were often forced to divide their time between agricultural and pastoral activities (Santoir, 1994), a difficult exercise with mixed results (Santoir, 1983: 151-160).

\footnotetext{
${ }^{2}$ Along with the droughts of the 1970-80s and the Mauritania-Senegal Border War of 1989.
} 
In their accounts, elderly members of the families interviewed recall drastic changes. Pastoralists consider themselves more mobile today than in the past. Previously, mobility was mostly limited to the rainy season. With the first rains families moved to the jeeri, where the older members would stay to sow millet while younger members headed south in search of the erratic first rains before returning once the rainy season set in. Currently, mobility begins in the dry season as pastures around nearby camps and boreholes are progressively exhausted. Pastoralists thus follow changing routes during a period when nutritional options are limited. Exclusion from the Valley has left pastoralists more exposed to the high variability of the regional climate. In an attempt to compensate for low-quality resources and frequent scarcities, pastoralists use expensive industrial cattle feeds, entailing difficult decisions about distribution within the herd. The women interviewed explain that being settled in the jeeri accentuates the seasonal character of dairy production and leads to the loss of valuable economic exchanges with agriculturalists (milk, cattle / cereal, money). Interventions in pastoral development have promoted a transition from systems practising agriculture and pastoralism, which had functional links in the Valley (resources and exchanges), towards specialised pastoral systems operating in a homogenous but variable ecological habitat which depend solely on the sale of cattle for the purchase of cereals, water and cattle feeds (Magnani, 2016: 298-325).

\section{La Laiterie du Berger, a pastoral social (agro)business}

Inspired by a Mauritanian dairy which has collected pastoral milk since 1989, the Laiterie du Berger (LdB) was founded by a young Senegalese veterinarian in 2006, at a time of growing denunciations of mass powdered milk imports in a country home to a large number of livestock farmers. The Valley and the city of Richard Toll were chosen because of the large herds in the hinterland, their good connections with the rest of the country by road and the presence of agro-industries, most notably the Compagnie Sucrière Sénégalaise (CSS). LdB has a transformation capacity of over 10,000 litres/day and sources its milk from around 600 pastoralists operating within a $35 \mathrm{~km}$ ring around the dairy. The collection area includes both the waalo and the jeeri, though the jeeri supplies the vast majority of the milk33.

Between 2006 and 2008 LdB transformed only local milk to create a diversified range of high-quality products. However, too little milk was collected to meet the dairy's needs (around 1000 litres/day in 2007) and it underwent major financial difficulties. In 2008 danone.communities, the social business ${ }^{4}$ foundation of the multinational group, became a shareholder, joining the founding Bathily family and the I\&P investment fund ${ }^{5}$, and revolutionised the dairy's activities. Other investors followed in the shape of Grameen Crédit Agricole Foundation and the ethical investment fund Phitrust in 2010 and Danone S.A. in 2012. LdB thus entered the mass market for curdled milk, a move in line with the stated objective of danone.communities to improve human nutrition. Danone provided key skills in areas including production, marketing and distribution, and a new range

\footnotetext{
${ }^{3}$ The presence of a more lucrative local market (500 FCA franc/litre compared to 225 CFA franc/litre paid by LdB at this time) discourages waalo livestock farmers from supplying LdB.

${ }^{4}$ An economic model based on reinvesting profits rather than generating dividends which aims to reconcile the company's profitability and its social dimension (Yunus et al. 2010).

${ }^{5}$ Investisseurs et Partenaires is an investment fund which finances small and medium-sized enterprises in Africa.
} 
(Dolima) was created to promote the products. Powdered milk was introduced to facilitate industrial production by rendering it less reliant on collected milk, which is in surplus during the rainy season but of limited supply and expensive in the dry season. In 2010 collection was restructured to reduce costs and support growth in the volume of marketed products (820 tonnes compared to 430 tonnes in 2007). The primary challenge was to ensure overall growth while reducing seasonal variability. A credit system for cattle feeds and measures to support production were implemented from 2011. These efforts bore fruit with the excellent returns of the 2011 campaign (915 tonnes of milk), though they were largely a result of the exceptional rainfall during the 2010 rainy season which allowed the pastoralists to limit their mobility. Enthusiasm quickly faded with the difficulties of the following year. The very dry 2011 rainy season meant that the pastoralists left the collection area early (from January 2012). In an attempt to encourage pastoralists to keep some of their dairy cows on site and so maintain collections, LdB proposed sugarcane residue, supplied by CSS, on a credit basis. Many pastoralists accepted because mobility was difficult and risky: water from the boreholes was expensive for transhumant pastoralists and pastures were rare along transhumance routes to the south. This strategy was successful in maintaining collection levels (637 tons by the end of the year) but pastoralists fell into heavy debt as they were forced to take out a considerable amount of credit in order to ensure the survival of the dairy cows and calves. Despite a high-quality 2012 rainy season the situation in 2013 was still uncertain. The effects of the 2011 drought continued to be felt because of the highly seasonal nature of bovine reproduction, meaning pastoralists left on transhumance to avoid their milk being seized as debt recovery. Collection totalled 700 tonnes for the year, while a record volume of 2,200 tonnes of marketable products was produced6. This major discrepancy served to underline the difficulties that the LdB faced in increasing and stabilising pastoral milk collection throughout the year?.

\section{Standardising systems or making them more diverse and flexible? A conceptual discrepancy}

This failure is not only technical, but above all conceptual, stemming from a poor understanding of pastoral systems and the logic behind them as well as of their attitudes to the LdB milk collections. As a general rule, participating in milk collection is profitable for pastoralists during the rainy season and for a part of the cold dry season, when milk production does not require feed inputs and dairy cows are at peak lactation. As milk prices at the weekly markets in the jeeri are very low during this season, the new commercial opportunities offered by LdB are very important in allowing pastoralists to get maximum value for their produce. However, during the dry season, selling to LdB is profitable only when natural pastures are available. As pastures become exhausted, which can happen earlier or later depending on the quality of the preceding rainy season, income from milk sales no longer covers the cost of inputs needed to feed the cattle (CSS sugarcane residues, industrial cattle feeds). The pastoralists who agree to keep their dairy cows at the main camp for collection by LdB therefore sell their milk at a

\footnotetext{
${ }^{6}$ LdB thus became Senegal's second largest dairy business.

7 These dynamics continued beyond the period of study. In 2018 LdB agreed to a rise in the price of milk to 300 CFA franc/litre. This increased purchase price is likely to have repercussions on collection that it would be interesting to follow.
} 
loss, at least during a part of the dry season ${ }^{8}$. To understand why some nevertheless choose to do so, it is necessary to look at factors beyond the desire to augment dairy production and income:

1) Continuous participation in milk collection during the dry season allows pastoralists to secure milk sales during the rainy season when there is surplus milk and the dairy prioritises its most loyal suppliers. This is particularly appealing to pastoralists with large herds because income from the milk produced by all dairy cows can cover debts and generate considerable profits.

2) Selling milk during the dry season is a means of obtaining feed inputs on credit, which is a major advantage especially during droughts. Given the current conditions of the inputs market, credit is essential for families with small herds and no other revenue sources. This can become a trap because debt can absorb all dairy income across several years, greatly disadvantaging women, who traditionally received it.

3) Pastoralists use collection services to consolidate a classical pastoral strategy. They split the family and the herd during the dry season, settling the most fragile members of both the families and herds (the elderly, children, dairy cows and calves) in the camp for the dry season. They are thus spared the difficulties of the transhumance while the rest of the family and the majority of the herd are more mobile. The dairy cows that remain ensure a milk supply for the elderly and children who cannot survive on rice alone.

Despite working together, industrial dairy producers and pastoralists have very different rationales and objectives. The dairies aim to encourage relatively specialised producers and stabilise pastoral milk production, without considering the economic viability of such a programme. This does not really reduce variability in production but its management and associated costs are externalised by the industrial producers and passed onto pastoralists. On the other hand, pastoralists look to get maximum use out of natural pastures, maintain the multifunctional quality of their systems and use the milk as much to feed their family and their calves as sell it. The pastoralists adapt the dairy's practices in order to make their systems more flexible and increase their options, and so better manage their operations in a difficult context.

The implicit dimensions of Intensification and Social Business: the interests of agrobusiness and the appropriation of pastoral resources

Having illustrated the parallel trajectory of development interventions and pastoralist practices in the Middle Valley, and more specifically the discrepancy between the objectives of industrial dairy producers and pastoralists in the LdB collection area, it is instructive to come back to the paradox underlined by Krätli. Fifty years of policy designed to encourage the stabilisation and artificialisation of pastoral systems have produced some effects the opposite to those intended. Far from becoming sedentary as planned, pastoralists have become more mobile, at the worst time of the year, without precise routes to follow, and despite unfavourable conditions for pastoral mobility. Similarly, instead of being sheltered from the dangers of climatic variability, the pastoralists are more

\footnotetext{
${ }^{8}$ In 2010-2011, an exceptional year, pastoralists were able to sell at a profit all year around; in 2011-2012, a severe drought year, they sold at a loss for the whole dry season (seven months); in 2013, a "normal" year, they sold at a loss only at the end of the dry season (three months).
} 
exposed to its risks. Indeed industrial feeds are an easy solution to keep cattle alive in hard times and their systematic use enables a partial decoupling of livestock population from pasture dynamics. However, feeds are expensive, excluding some pastoralists, accentuating inequalities and necessitating difficult decisions about distribution. Finally, they provide only very partial compensation for the loss of access to the resources of the Valley, which are diverse and so complement the pastures of the jeeri. LdB's intended artificialisation of pastoral systems thus collides with economic and ecological constraints.

Given that the technoscientific model of intensification has engendered disruption and upheaval while failing to live up to most of its promises, why has it been so persistent? Despite its destructuring effects on the ecological basis of pastoral production, the model is presented by industrial dairy producers as the only way to ensure the survival of pastoralism in the face of shrinking pastoral land. Indeed a new process of agricultural colonisation, originating in the Valley, is underway. With possibilities in the Valley now exhausted, a number of agrobusiness projects have channeled water from the River so that land in the jeeri rangelands can be cultivated. The SenhuileSenethanol project has appropriated 20,000 ha of the Ndiael nature reserve around Lake Guiers. Part of the forest, which is an important resource to pastoralists, has been destroyed, while the infrastructure has encircled villages and fragmented the surrounding area, provoking a strong reaction from inhabitants and civil society in Senegal (Koopman, 2012a; Word, 2014; RE:COMMON, 2015). Another scheme around Lake Guiers, the Projet de Développement Inclusif et Durable de l'Agrobusiness (PDIDAS), funded by the World Bank, plans to develop 10,000 ha for private investment in agriculture. However, the implementation of the project has proven difficult because of disagreements over the allocation of land. Finally, as part of its development plan, CSS has acquired approximately 5,000 additional hectares (meaning a total of 15,000 ha) of rangelands in the jeeri. While CSS provides a considerable quantity of agricultural residues through the dairy, storage and delivery costs must be met by the pastoralists. Free herbaceous resources are thus removed, to be replaced by agricultural residues which have to be bought. LdB's decisions seem contradictory when one considers that removing rangeland and replacing it with the sale of feeds will likely limit milk production in the jeeri and accentuate its seasonality. Through their strategic partnership with the sugar industry, a major actor in the local politics of land and water use, the industrial dairy producers indirectly support the land grabbing underway. The technoscientific model of intensification thus continues to play a major political role, falling short of and indeed contradicting the discourse reflecting the characteristics of the area. Firstly it is the keystone of the opportunistic alliance between LdB and CSS, serving as an instrument to define shared representations and common interests, following the definition of "development model" given by Mosse $(2004,2005)^{9}$. Secondly, it helps to legitimise the interests of agrobusiness and depoliticise the appropriation of natural resources, representing an example of "governing by rendering technical" (Ferguson, 1990; Murray Li, 2007).

Questioning the role of livestock intensification leads us to examine how successfully social business meets its stated aim of finding a balance between societal and commercial objectives. The LdB social business is presented as a novel economic model that brings together a range of diverse actors: foundations and investment funds, a

\footnotetext{
${ }^{9}$ In the work cited, Mosse shows that rather than shaping practices on the ground, "development models" (e.g. "participation", "community development", etc.) function as systems to ensure shared and coherent representations and maintain political support for a range of actors with different interests.
} 
multinational dairy, NGOs, backers, international cooperation agencies and research institutions. The model pools expertise from strategic domains and ensures favourable access to public development funds and private funding. Danone's central role in guiding and supporting LdB is in line with its strategy to expand in Africa, where it has acquired a number of major dairies since the end of the 2000s (Bouchet, 2016) ${ }^{10}$. LdB allows Danone to promote a positive image of the company, a central concern in today's world, but also to help run, with limited investment, a company which is now the second biggest player in the Senegalese market. Moreover, Danone has acquired valuable experience in a number of domains, such as building and running formal and informal commercial channels, experimenting with models of local production, understanding the West-African market, and creating a successful brand.

More generally, the social business model, like the corporate social responsibility model, allows actors in agrobusiness to not only forge partnerships with each other, but also develop broad coalitions of actors likely to support the legitimisation of their political stances and to create favourable power relations within international development decision-making circles (Binet, 2014). This mirrors the general evolution of aid, in which private actors play an ever more central role (Gabas et al., 2014).

Yet, when measured against the societal objectives that Fulani pastoralists consider important, the LdB project appears much less novel than its economic model. The dairy has indeed created a formal milk market that provides pastoralists an important opportunity to commercialise milk, while pastoralists can adapt LdB's incentive programmes to give themselves more room for manœuvre in running their livestock systems in difficult circumstances. However, the LdB social business ignores the historical factors behind fundamental changes in pastoral practices and resource management, as well as the power relations and political choices that underpin them. By working in an opportunistic and strategic partnership with CSS, LdB shows itself to be incapable of working to reform the models of land use and resource management that disadvantage pastoralists. At the same time the spread of this new model of agricultural colonisation in the hinterland of the Valley risks compromising the durability of pastoral systems and creating conflict. The Senegalese state accords absolute priority to investments in agrobusiness in the Valley, to the point of developing strategies to try to circumvent existing land law, which was judged insufficient to "safeguard" private investors (Bourgoin et al., 2016: 15)11. This policy is pursued despite the few available studies of the consequences of growing agrobusiness investment in the Valley showing mixed results in terms of integrating farming systems and creating salaried employment, and an indisputably negative impact on pastoral activities (Soullier et al., 2016).

This case study provides a good illustration of the dynamics of land fragmentation and the private use of resources which are spreading rapidly in the Sahel, particularly in humid zones. The privatisation of strategic areas once shared between multiple uses in different seasons based on negotiations between different social and professional groups, has a major impact on pastoralism. It is also an example of the contradictions that characterise the actions

\footnotetext{
${ }^{10}$ Notably Fan Milk in Ghana, Brookside in Kenya and the Centrale laitière in Morocco, with a total value of more than one billion euros.

${ }^{11}$ In order to facilitate the allocation of 20,000 ha to Senhuile-Senethanol, the state removed the protected status of the peripheral zone of the Ndiael reserve, land over which it had direct control. To "safeguard" expected private investments in the PDIDAS project, the state has tried without success to introduce a system of land registration that would circumvent local authorities and so contravene existing law.
} 
of development aid agencies: against a backdrop of multiple crises and revolts across large parts of the Sahel, they proclaim a renewed interest in pastoralism and reinvest in pastoral development after decades of neglect, all while continuing to favour the implementation of policies which destructure and disadvantage pastoral systems.

\section{Conclusion}

We have thus shown how, in the context under study, development interventions shaped by the technoscientific model of intensification have failed in their attempt to standardise and stabilise pastoral systems in the Valley. Production has become more variable and pastoral mobility more unpredictable and varied from year to year.

In this context LdB's actions have had contradictory effects. On the one hand, the intervention of industries which aim to stabilise and artificialise livestock farming is adapted by pastoralists who, making use of the diversity and flexibility of their systems, give themselves a greater range of strategies to better manage an array of complex constraints over which they have little control. On the other hand, the technicist approach of industrial dairy producers and their partners serves to justify, depoliticise and reproduce decisions which serve the interests of agrobusiness, such as replacing pastoral resources with feed inputs that must be bought. These dynamics exacerbate the constraints acting on the pastoralists.

It is therefore necessary to underline the political dimensions and power relations hidden in the technicisation of pastoral development interventions and include them in an open and informed public debate: the lack of land rights adapted to the specific needs of pastoralism leads to land grabbing, exclusion from strategic resources in humid zones, and precarious access to public services in pastoral areas. Equally, it is clearly imperative to deconstruct the rhetoric about reconciling the demands of profit seeking with social development, and to examine how it helps to legitimise the growing role of private business in shaping and implementing public development initiatives. In this case study, social business appears more like a means to exploit the vacuum left by public authorities incapable of devising inclusive territorial development policies in drylands.

The new wave of agricultural colonisation in the Senegal River Valley hinterland testifies to the revival and expansion of a longstanding tendency for spatial specialisation in agriculture and livestock farming in the drylands of West (Koopman, 2012b) and East Africa (Fratkin, 2014; Galaty, 2014; Schlee, 2014). It is thus urgent to fundamentally rethink land use patterns in humid zones and irrigated areas to ensure different users have access to resources and to promote functional interaction between agricultural and pastoral activities.

The case study at the centre of the article perfectly illustrates these contradictions. The destruction of part of the Ndiael reserve has had serious consequences in reducing the diversity of agro-ecosystems, with negative effects for both socioeconomic activities (small-scale farming, pastoralism, foraging) and the environment. Given the fragmentation and partitioning of humid and dry zones in the region, further developments in dry zones are likely to accentuate these dynamics and their negative effects.

Changing the paradigm will rather require preserving or encouraging new complementarities between agricultural and pastoral activities in diversified ecological zones, in an approach founded on understanding that 
promotes interaction and cogeneration between the different communities of the living environment. Resources would thus not be taken for granted and seen as a stock to be exploited in a more or less considerate manner, but rather understood as the product of interactions between local societies and their environment, mediated through herds of ruminants in pastoral settings (Hubert et Ison, 2011; Krätli, 2017b). Simply transferring agricultural residues from irrigated land reserved for crop production to pastoral areas is not a renewable practice. It entirely ignores ecological processes, while also raising the problem of the cost of collecting, stocking and distributing the residues in question.

Rethinking current models of development requires major shifts in conceptualisation. Rather than being seen as existing independently of human activities, "natural" resources must be considered as social constructions shaped by the practices, norms, values and references underpinning production systems (Figuié et Hubert, 2012: 307). This requires shifting the focus from a static and linear analysis to a dynamic that encompasses processes, relationships and contexts. Knowledge, production practices and forms of social organisation must be seen as key elements of these processes (Krätli, 2015: 82). There lie, in our opinion, the central challenges facing the future of pastoralism not only in the Senegal River Valley but, more generally, in the African drylands.

\section{Bibliography}

Ancey, V., and G. Monas. 2005. Le pastoralisme au Sénégal, entre politique «moderne » et gestion des risques par les pasteurs. Revue Tiers Monde, $4:$ 761-783.

Ancey, V., A. Ickowicz, I. Touré, A. Wane, A.T. Diop. 2009. La vulnérabilité pastorale au Sahel: portée et limites des systèmes d'alerte basés sur des indicateurs. In Elevage, richesse des pauvres. Coordinated by Bernard FAYE, Guillaume DUTEURTRE. Ed. Quae, p. 117-132.

Baroin, C. 2003. L'hydraulique pastorale, un bienfait pour les éleveurs du Sahel ? Afrique contemporaine, 1, p. 205-224.

Barral, H. 1982. Le Ferlo des forages. Gestion actuelle et ancienne de l'espace pastoral. Dakar : ORSTOM, 85 p.

Batterbury, S. 1998. Local environmental management, land degradation and the "gestion des terroirs" approach in West Africa: Policies and Pitfalls. Journal of International Development, 10, p. 871-898.

Behnke, R.H., and I. Scoones. 1993. Rethinking range ecology: implications for rangeland management in Africa. In R.H. Behnke, I. Scoones, and K. Kerven (eds.) Range ecology at disequilibrium: New models of Natural Variability and Pastoral Adaptation in African Savannas. London, Overseas Development Institute.

Behnke, R.H., and M. Mortimore (Ed.). 2016. The end of Desertification? Disputing Environmental Change in the Drylands. Springer Earth System Sciences.

Bernus, E. 1984. Les causes de la désertification : les thèses en présence. Bulletin de la Société Languedocienne de Géographie, tome 18, fascicule 3-4, p. 159-165.

Bernus, E. 1990. En guise de conclusion : las pasteurs nomades africains, du mythe éternel aux réalités présentes. Cahiers des sciences humaines, 26 (1-2), p. 267-280.

Bernus, E. 1992. Hydraulique pastorale et gestion des parcours. In L'aridité : une contrainte au développement : caractérisation, réponses biologiques, stratégies des sociétés. Ed. by E. LE FLOC'H, Michel GROUZIS, Antoine CORNET, Jean-Claude BILLE. Paris : ORSTOM, p. 556-563.

Binet, N. 2014/1. Le rôle des entreprises et des fondations privées dans la gouvernance mondiale agricole et alimentaire. Mondes en développement, $\mathrm{n}^{\circ} 165$, p. 23-36.

Bonnet, B., O.M. Ousseini, and I.E.H. Attoumane. 2015. Une famille et son système d'exploitation pastoral sans frontières, entre Niger, Tchad et Nigeria. In P.M. Bosc, J.M. Sourisseau, P. Bonnal, P. Gasselin, E. Valette, J.F. BELIERES (coord.) Diversité des agricultures familiales. Ed. Quae, p. 263-268. 
Boone, R.B., S.B. Burnsilver, and R.L. Kruska. 2008. Comparing Landscape and Infrastructural Heterogeneity within and between Ecosystems. In Fragmentation in Semi-Arid and Arid Landscapes: Consequences for Human and Natural Systems. Ed. by Kathleen A. GALVIN, Robin S. REID, Roy H. BEHNKE Jr., N. THOMPSON HOBBS. Springer, p. 341-369.

Bourgoin J., E. Valette, D. Diop. 2016. Co-construction d'un Observatoire en accompagnement des politiques foncières au Sénégal. In: Le développement à l'épreuve des régions frontalières. Gatineau: ASRDLF, 19 p.

Bouchet, C. 2016. Africa: a new potential of growth for Danone through multiple acquisitions. Strategic Direction, Vol. 32, 9, p. 28-31.

Boutillier, J.L., P. Cantrelle, J. Caussé, C. Laurent, and T.H. Ndoye. 1962. La Moyenne Vallée du fleuve Sénégal. Presses Universitaires de France. 368 p.

Boutillier, J.L., J. Schmitz. 1987. Gestion traditionnelle des terres et transition vers l'irrigation. Le cas de la vallée du Sénégal. Cahier Sci. Hum., 23 (3-4), p. 533-554.

Boutrais, J. 1989. Le zébu et le vétérinaire : un siècle d'histoire de l'élevage en Afrique de l'Ouest et du Centre. In Tropiques : lieux et liens : florilège offert à Paul Pelissier et Gilles Sautter. Ed. by Benoît ANTHEAUME, Chantal BLANC-PAMARD, Jean-Louis CHALEARD et al. Paris, ORSTOM, p. 161-171.

Casciarri, B. 2013/2. Systèmes sociotechniques, savoirs locaux et idéologies de l'intervention. Deux exemples de gestion de l'eau chez les Pasteurs du Soudan et du Maroc. Presses de Sciences Po-Autrepart, 65, p. 165-190.

Davis, D.K. 2016. The Arid Lands: History, Power, Knowledge. Massachusetts Institute of Technology.

Déclaration de N’Djamena sur la contribution de l'élevage pastoral à la sécurité et au développement des espaces saharosahéliens. 29 mai 2013.

De Haan, C. 1994. An overview of the World Bank's involvement in pastoral development. Overseas Development Institute, Pastoral Development Network.

Ellis, J.E., D.M. Swift. 1988. Stability of African pastoral ecosystems: Alternate paradigms and implications for development. Journal of Range Management 41 (6).

Ferguson, J. 1994. The Anti-Politics Machine: "Development", Depoliticization and Bureaucratic Power in Lesotho. The University of Minnesota Press.

Figuié, M., and B. Hubert. 2012. Pour qui, pourquoi une ressource est-elle jugée dégradée ? Pâturages et agricultures familiale au Brésil. Natures Sciences Sociétés, 20 : 297-309.

GALVIN, K.A., S. Robin, R. REID, R.H. BEHNKE Jr., and N. THOMPSON HOBBS (Ed.). 2008. Fragmentation in Semi-Arid and Arid Landscapes: Consequences for Human and Natural Systems. Springer, 411 p.

Fratkin, E. 1997. Pastoralism: Governance and Development Issues. Ann. Rev. Anthopol., 26, p. 235-261.

Fratkin, E. 2014. Ethiopia's Pastoralist Policies: Development, Displacement and Resettlement. Nomadic Peoples, 18: 94-11.

Gabas, J.J., D. Pesche, V. Ribier, and B. Campbell. 2014. Nouveaux regards sur la coopération pour le développement et ses transformations. Mondes en développement 165 (1): 7-22.

Galaty, J. 2014. Unused land and unfulfilled promises: justifications for displacing communities in east Africa. Nomadic Peoples, 18: 80-93.

Griffon M., F. Jacquet, E. Lemaire, I. Avelange, M. Barbier, B. Chevassus-au-Louis, B. Hubert, S. Treyer, J. Valentin Christian, J. Gielen, M. Fillon. 2015. Emergence de l'agroécologie et perspectives pour le futur : les programmes ADD Systerra Agrobiosphère. Cahiers de l'ANR, 8, 50 p.

Government of Kenya. 2012. Sessional Paper n8 on National Policy for Sustainable Development of Northern Kenya and other Arid Lands, Releasing Our Full Potential. Ministry of State for Development of Northern Kenya and Other Arid Land, Nairobi.

Hesse, C., and B. Thébaud. 2006. Will pastoral legislation disempower pastoralists in the Sahel? Indigenous Affairs, 1/06, p. 1423.

Hodgson, D.L. 1996. Images \& Interventions: The Problems of Pastoralist Development. In The poor are not us. Poverty and Pastoralism. Ed. by David M. ANDERSON, Vigdis BROCH-DUE. London: James Currey, p. 221-239.

Homewood, K. 2008. Ecology of African Pastoralist Societies. James Currey, Ohio University Press, UNISA Press.

Hubert, B., and R. Ison. 2011. Institutionalising understanding: From resource sufficiency to functional integrity. In Trish KAMMILI, Bernard HUBERT, Jean-François TOURRAND, A paradigm shift in livestock management: From Resource sufficiency to Functional Integrity. Ed. by. Cardère éditeur, p. 11-17.

Khazanov, A. 1994. Nomads and the outside world. University of Wisconsin Press.

Koopman, J. 2012a. Lands grab, government, peasant and civil society activism in the Senegal River Valley. Review of African Political Economy, 39:134, 655-664. 
Koopman, J. 2012b. Will Africa's Green Revolution squeeze African family farmers to death? Lessons from small-scale highcost rice production in the Senegal River Valley. Review of African Political Economy, 39:133, 500-511.

Krätli, S. 2007. Cows who choose domestication. Generation and management of domestic animal diversity. 327 p. PHD Thesis, Institute of Development Studies, University of Sussex.

Krätli, S. 2008. Time to outbreed animal science? A cattle-breeding system exploiting structural unpredictability: the Wodaabe herders in Niger. STEPS Working Paper 7, Brighton: STEPS Center, 35 p.

Krätli, S. 2015. Valuing variability: New Perspectives on climate resilient drylands development. IIED. Ed. by de Jode, H.

Krätli, S. 2016. Discontinuity in pastoral development: time to update the method. Rev. Sci. Tech. Off. Int. Epiz. 35 (2), p. 485 497.

Krätli, S. 2017a. Pastoral Localization of Humanitarian Aid: The need to re-qualify the pastoral context. African Study Monographs, Suppl. 53: 141-146.

Krätli, S. 2017b. Pastoralist Landscapes and natural resources. Seminar 695 - July 2017.

Krätli, S., and N. Schareika. 2010. Living off uncertainty: The intelligent Animal Production of Dryland Pastoralists. European Journal of Development Research, vol. 22 (5), p. 605-622.

Krätli S., M. Monimart, B. Jallo, J. Swift, and C. Hesse. 2013. Evaluation et capitalisation de 20 ans d'interventions du groupe AFD portant sur le secteur de l'hydraulique pastorale au Tchad. Londres : IIED, $141 \mathrm{p}$.

Landais, E. 1990. Sur les doctrines des vétérinaires coloniaux français en Afrique noire. Cah. Sci. Hum, 26 (1-2), p. 33 -71.

Magnani, S. 2016. Le Lait local au Sénégal : Intensifier pour développer? Dynamiques socio-techniques et Anthropologie des pratiques. PHD Thesis, Marseille: EHESS, p. 392.

Marty, A. 1993. La gestion de terroirs et les éleveurs : un outil d'exclusion ou de négociation. Tiers-Monde, 34, ${ }^{\circ}$ 134, p. 327344.

Mosse, D. 2004. Is Good Policy Unimplementable? Reflections on the ethnography of Aid Policy and Practice. Development and change, 35 (4), p. 639-671.

Mosse, D. 2005. Cultivating development. An Ethnography of Aid Policy and Practice. London: Pluto Press, 315 p.

Murray Li, T. 2007. The Will to Improve. Governmentality, Development, and the Practice of Politics. Durham \& London: Duke University Press, $374 \mathrm{p}$.

Oxby, C. 1981. Ranches collectifs en Afrique. Rome: FAO, 44 p.

CATLEY, A., J. LIND and Ian SCOONES (Ed.). 2013. Pastoralism and Development in Africa: Dynamic change at the margins. Routledge, p. 295.

Pouillon, F. 1990. Sur la «stagnation» technique chez les pasteurs nomades: Les Peuls du Nord-Sénégal entre l'économie politique et l'histoire contemporaine. Cahiers des sciences humaines, 26 (1-2), p. 173-192.

RE:COMMON. Sénégal. Comment on accapare la terre, la saga Senhuile-Senethanol continue. 2015,37 p. http://www.recommon.org/eng/au-senegal-laccaparement-des-terres-est-sur-le-point-dimploser/ [accessed november 2018]

Roe, E., L. Huntsinger, K. Labnow. 1998. High reliability pastoralism. Journal of Arid Environments, 39, p. 39-55.

Roe, E. 2013. Making the most of mess. Reliability and policy in today's management challenges. Durham, NC, Duke Univ. Press, $224 \mathrm{p}$.

Santoir, C. 1983. Raison pastorale et développement. Les problèmes des Peul sénégalais face aux aménagements. Paris : Travaux et Documents de l'ORSTOM, $185 \mathrm{p}$.

Santoir, C. 1994. Décadence et résistance du pastoralisme. Les Peuls de la vallée du fleuve Sénégal. Cahiers d'Etudes Africaines, vol. 34, n 133-135, p. 231-263.

Sayre, N.F. 2008. The genesis, History, and Limits of Carrying Capacity. Annals of the Association of American Geographers, 98:1, 120-134.

Sayre, N.F. 2017. The Politics of Scale: A History of Rangeland Science. The University of Chicago Press.

Schareika, N. 2003. Know to move, move to know ecological knowledge and herd movement strategies among the Wodaabe of southern Niger. Rome: FAO.

Schlee, G. 2013. Why States still destroy Pastoralism and how they can learn that in their own interest they should not. Nomadic People, 17, 2: 6-1.

Schmitz, J. 1986. L'état géomètre : les leydi des Peuls du Fuuta Tooro et du Maasina. Cahiers d'Etudes Africaines, 103, XXVI-3, p. 349-394. 
Scoones I. (ed.) 1994. Living with uncertainty. New directions in pastoral development in Africa. London: Intermediate Technology Publications, International Institute for Environment and Development.

Soullier, G., P. Moustier, A. Ba, and J. Bourgoin. 2016. Les effets des agrobusiness sur les petits producteurs dans la vallée du fleuve Sénégal : résultats de trois études de cas. Montpellier: CIRAD-ES-UMR MOISA-CIRAD-ES-UMR TETIS, 34 p.

Swift, J. 1996. Desertification. Narratives, Winners and Losers. In The lie of the land: challenging received wisdom on the African environment. Ed. By Melissa LEACH \& Robin MEARNS. London: The International African Institute, p. 73-90.

Tache, B. 2012. Rangeland enclosures in Southern Oromia, Ethiopia: an innovative response or the erosion of common property resources? In Pastoralism and Development in Africa: Dynamic change at the margins. Ed. by Andy CATLEY, Jeremy LIND and Ian SCOONES. Routledge, p. 295.

Thébaud, B. 1990. Politiques d'hydraulique pastorale et gestion de l'espace au Sahel. In Sociétés pastorales et Développement. Ed. by Edmund BERNUS and François POUILLON. Cahiers des Sciences Humaines (ORSTOM), vol. 26, n 1-2, p. 13-31.

Thébaud, B., S. Batterbury. 2001. Sahel pastoralists: opportunism, struggle, conflict and negotiation. A case study from Eastern Niger. Global Environmental Change, 11, p. 69-78.

Thébaud, B., H. Greli, S. Miehe. 1995. Recognising the effectiveness of Traditional Pastoral Practices: Lessons from a controlled grazing experiment in Northern Senegal. London: IIED, Paper $n^{\circ} 55,33$ p.

Touré, O., J. Arpaillange. 1986. Peul du Ferlo. Paris: L'Harmattan.

Turner, M.D. 2011. The New Pastoral Development Paradigm: Engaging the Realities of Property Institutions and Livestock Mobility in Dryland Africa. Society \& Natural Resources: An International Journal, 24 (5), p. 469-484.

Union Africaine, 2013. Cadre stratégique pour le pastoralisme en Afrique : Sécuriser, protéger et améliorer les vies, les moyens de subsistance et les droits des communautés pastorales. UA, Addis Abéba, p. 56.

Word, J. 2014. Sacrifier notre Futur: Comment le projet Senhuile-Senethanol menace l'environnement et détruit les communautés locales. The Oakland Institute, $16 \mathrm{p}$.

Yunus, M., B. Moingeon, L. Lehmann-Ortega. 2010. Building Social Business Models: Lessons from the Grameen Experience. Long Range Planning, 43: 308-325. 